\title{
MALATYA İLİNDE GELENEKSEL BAĞCILIK UYGULAMALARI
}

\author{
Traditional viticulture applications in Malatya province
}

Tahir MACIT ${ }^{1}$

Erdoğan ÇÖÇEN * 1

Cemil ERNIM ${ }^{1}$

Nedim GÜLTEKIN ${ }^{1}$

Makbule YANAR $^{1}$

Yüksel SARITEPE ${ }^{1}$

*Sorumlu Yazar: elmas29@gmail.com

${ }^{1}$ Kayısı Araştırma Enstitüsü Müdürlüğü, Malatya

ORCID (Yazar Sırasına Göre):

(iD) 0000-0001-9652-8202

(D) 0000-0003-2052-949X

(D) $0000-0002-0586-8963$

(iD $0000-0003-2238-0115$

(iD) 0000-0002-7760-6292

(D) 0000-0002-1042-7062

Gönderilme Tarihi: 21 Ocak 2019

Kabul Tarihi : 28 Mart 2019

\section{ÖZET}

Geleneksel kavramlarveuygulamalarülkeleriçintarihi miras niteliğindedir. Pek çok uygarlığa ev sahipliği yapan Anadolu, tarımsal alanda oldukça zengin bir kültürel mirasa sahiptir. Ülkemizde geleneksel giyim kuşam, geleneksel gıdaların üretimi ve geleneksel mimari uygulamalarının derlenmesi ve muhafazasına yönelik pek çok çalışma yapılmıştır. Ancak geleneksel tarım tekniklerinin derlenmesine yönelik çalışmalar sınırlı düzeydedir. Oysa somut olmayan kültürel miraslardan olan bu tarımsal birikimin derlenerek muhafaza edilmesi önem arz etmektedir. Ülkemizin önemli meyvecilik merkezlerinden olan Malatya ilinde bağcıllı̆ın tarihi çok eskilere dayanmaktadır. İlde gerçekleștirilen arazi çalışmalarında ve çiftçi ziyaretlerinde geleneksel bağcılıkta çok farklı budama yöntemlerinin, dikim, hasat ve bakım tekniklerinin, kelime ve kavramların kullanıldığı görülmüştür. Tarım ve Orman Bakanlığı'nca desteklenen ve 2014-2016 yılları arasında yürütülen bu çalışmada Malatya ili geleneksel bağcılığında uygulanan kültürel işlemler ile terim ve kavramların derlenerek muhafazası amaçlanmıştır. 
Çalışmanın materyalini ilde geleneksel yöntemlerle bağcılık yapan üreticilerden elde edilen bilgiler oluşturmuştur. $\mathrm{Bu}$ bilgiler, ilde geleneksel bağcılı̆̆ın yoğun olarak yapıldığ1 Battalgazi, Yeşilyurt, Arapkir ve Doğanşehir ilçelerinde belirlenen üreticilerle yüz yüze görüşmeler yapılarak derlenmiştir. Çalışma sonunda geleneksel bağcilıkta kullanıldı̆̆ belirlenen 37 farklı terim ve kavram güncel anlamlarıyla birlikte kayıt altına alınmıştır. Ayrıca geleneksel bağcılıkta uygulanan bağ tesisi, budama yöntemleri, zirai mücadele ile kurutma ve depolama teknikleri de derlenmiştir.

Anahtar Kelimeler: Üzüm, Asma, Geleneksel bağcılık, Bağcılık teknikleri, Malatya

\section{ABSTRACT}

Traditional concepts and practices are historical heritage for countries. Anatolia, home too many civilizations, has a rich cultural heritage in the agricultural area. In our country, a lot of work has been performed on the collection and preservation of traditional clothing, production of traditional foods and traditional architectural practices. However, studies on the collection of traditional agricultural techniques are limited. However, it is important to collect and maintain this agricultural knowledge which is an intangible cultural heritage. The history of viticulture in Malatya, which is one of the most important fruit growing centers of our country, is based on old times. In the field studies and farmer visits in the province, it was observed that many different pruning methods, planting, harvesting and maintenance techniques, terms and concepts were used in traditional viticulture. In this study, which was supported by the Ministry of Agriculture and Forestry and carried out between 2014-2016, it was aimed to collect and maintain the cultural processes, terms and concepts applied in the traditional viniculture of Malatya. The material of the study is composed of information obtained from producers who are grape growers in the province. This information has been obtained by face-to-face interviews with the growers determined in Battalgazi, Yeşilyurt, Arapkir and Doğanşehir districts where traditional viniculture is done intensively. At the end of the study, 37 different terms and concepts, determined to be used in traditional viticulture, were recorded together with their current meanings. In addition, the vineyard establishment, pruning techniques, pest control, drying and storage techniques applied in traditional viticulture were also collected.

Keywords: Grape, Grapevine, Traditional viticulture, Viticultural techniques, Malatya

\section{GİRIŞ}

Toplumların tarihsel süreç içinde ürettiği ve nesilden nesile aktardığı her türlü maddi ve manevi özelliklerin tamamına kültür denir. Kültür, bir toplumun kimliğini yansitır (Karakaya ve Tiske, 2009). Köklü bir tarihi olan Türk milleti tarihsel süreç içerisinde biriktirdiği önemli bir kültürel zenginliğe sahiptir (Altun, 2015). Ülkemiz UNESCO'nun Somut Olmayan Kültürel Mirasın Korunması Sözleşmesine 
27 Mart 2006 tarihinde taraf olmuştur. Somut olmayan kültürel miraslar kısa sürede oluşmazlar ve geleneksel uygulamalar bu somut olmayan kültürel miras içerisinde yer alır (Arığlu ve ark., 2015).

İnsanlığın beşiği olan Anadolu pek çok uygarlıklara ev sahipliği yapmıştır. Eski Anadolu'nun önemli kültürlerinden olan Hitit, Frig, Urartu ve Lidya ekonomisinin temelini tarım ve hayvancılık oluşturmuştur. Hititler tarım ürünlerinden buğday, arpa, bezelye, soğan, keten, incir, zeytin, üzüm, elma ve nar yetiştiriciliği yaparken, Frigler ise bağc1lıkta oldukça önemli bir yere sahiptirler. Urartular ve Lidyalılar'da diğer tarım ürünlerinin yanı sıra üzüm ve şarap üretmişlerdir (Keskin, 2011; Bülbül 2017). Asmanın gen merkezlerinin kesiştiği ve ilk kez kültüre alındığg coğrafyanın merkezinde olan ülkemiz, bağcılığa uygun iklime sahip olmasıyla dünyanın önemli üzüm üreticisi ülkeleri içerisinde yer almaktadır (Çelik ve ark.,1998; Keskin, 2017).

Yaş ve kuru üzümün yanı sıra işlenerek; sirke, pestil, pekmez ve şarap gibi değişik ürünlerin de elde edildiği üzümler, bağcılık faaliyeti ile uğraşan üreticiler için önemli bir gelir kaynağ1 oluşturmakta ve ülke ekonomisine önemli katma değer sağlamaktadır (Ergenoğlu ve Tangolar, 2000). Diğer yandan kırsal turizm içerisinde yer alan bağcılık turizminin de son yıllarda gelişmekte olduğu ve ülkemizin bu anlamda önemli bir potansiyele sahip olduğu bildirilmektedir (Türkben ve ark., 2012; Köse ve Çelik, 2017; Keskin ve ark., 2018).
Bağcılık faaliyeti eski tarihlerden beri Anadolu insanının önemli tarımsal uğraşlarından ve gelir kaynaklarından birini oluşturmuştur. Zaman içerisinde tarihsel derinliği olan bu uğraşa ait kültürel miras niteliğinde gelenekselleşen çeşitli uygulamalar ile tanımlar ortaya çıkmıştır.

Doğu Anadolu Bölgesinde yer alan Malatya ili ülkemizin önemli meyvecilik merkezlerindendir (Ülkümen, 1938). Malatya kayısı üretimi ile öne ç1kmakla birlikte pek çok 1lıman iklim meyve türünün yetiştiriciliği başarıyla yapılmaktadır (Bayındır ve ark., 2018; Çöçen ve ark., 2018). İlde bağcılığın tarihi çok eskilere dayanmaktadır. İlde bulunan Aslantepe höyüğünde yapılan kazılarda, kalkolitik çağda Malatya'da üzüm ve meyve üretiminin yapıldığına dair bulgular elde edilmiştir (Anonim, 2018).

Yakın tarihe kadar üretim alanı ve üretim miktarı itibariyle Malatya ilinde birinci sirada yer alan bağcılık, günümüzde kayısı ve elmadan sonra üçüncü sıraya gerilemiştir. İlde 2010 yılında 61.870 da alanda 16.114 ton üzüm üretimi gerçekleşirken, 2018 yılında üretim alanının 41.487 dekara ve üretim miktarının ise 14.877 tona gerilediği görülmektedir (Anonim, 2019; TUIK, 2019).

Üretim alanları ve üretim miktarındaki bu düşüşe rağmen bağcılık faaliyeti ilde hala önemini korumaktadır. Malatya ilinde modern bağ tesislerinin yanı sıra geleneksel yöntemlerle de bağcılık yapılmaktadır. İlde gerçekleştirilen çalışmalarda ve çiftçi ziyaretlerinde geleneksel bağcılıkta farklı budama yöntemleri, dikim, 
hasat ve bakım tekniklerinin yanı sıra, farklı terim ve kavramların kullanıldığı görülmüştür. Bağcılık faaliyetinin giderek azalmakta olduğu ilde, somut olmayan kültürel miras niteliğinde olan bu geleneksel bağcılık yöntemleri ile terim ve kavramların derlenerek muhafaza altına alınması önem arz etmektedir.

Tarım veOrmanBakanlığı, TarımsalAraştırmalar ve Politikalar Genel Müdürlügüunce desteklenen ve 2014-2016 yılları arasında yürütülen bu çalışmada, Malatya ilinde geleneksel bağcılığın yoğun olarak yapıldığı Battalgazi, Yeşilyurt, Arapkir ve Doğanşehir ilçelerinde belirlenen üreticilerle yüz yüze görüşmeler sonucunda elde edilen bilgiler doğrultusunda ilde uygulanmakta olan geleneksel bağcılık yöntemleri ile geleneksel bağcılıkta kullanılan terim ve kavramlar derlenmiştir. Çalışmada soyut bir kültürel miras niteliğinde ve kaybolma tehlikesi altında olan geleneksel bağcılık uygulamalarının kayıt altına alınması amaçlanmıştır.

\section{GELENEKSEL BAĞCILIKTA KULLANILAN TERIM VE KAVRAMLAR}

Çalışmada geleneksel bağcılıkta 37 farklı terim ve kavramın kullanıldığı belirlenmiş ve bu terim ile kavramların güncel anlamları alfabetik sıraya göre Çizelge 1'de verilmiştir. Bu terim ve kavramların geleneksel adlandırmalarında yöresel konuşma dilinin yanı sıra bağcılık terimlerinin de etkili olduğu görülmüsştür.

\section{GELENEKSEL BAĞCILIKTA BAĞ} TESİSI VE KÜLTÜREL UYGULAMALAR

\subsection{Bağ tesisi}

İlde geleneksel bağc1lıkta bağ tesis edilirken, bölgenin coğrafi durumu ve iklim özeliklerine göre çeşit seçimi yapılmaktadır. Güneye bakan ve rakımı düşük sıcak bölgelerde sofralık ve şıralık çeşitlerle bağ tesis edilirken, kuzeye bakan alanlarda kurutmalık siyah (özellikle Banazı Karası) üzüm çeşitleri tercih edilmektedir.

Yeni bağ tesisinde ilk önce dikim çukurları (ocaklar) hazırlanmaktadır. İlde geleneksel bağcılık kurak şartlarda ve sulama yapılmadan gerçekleştirildiğinden dolayı, taban suyundan faydalanmak için oldukça derin bir şekilde 2 $\mathrm{m}$ uzunluğunda ve $1.5 \mathrm{~m}$ derinliğinde, $2 \times 2 \mathrm{~m}$ aralıklarla açılmaktadır. Bağ tesisinde sonbahar döneminde sağlıklı omcalardan kesilen dipçikli (eğriceli) çelikler kullanılmaktadır. Bu dipçikli çelikler sonbahar döneminde desteler halinde hazırlanıp bağlanarak, mümkünse akarsuda değilse durgun suda 10-15 gün boyunca güneş görmeyecek şekilde bekletilmekte ve daha sonra hazırlanan çukurlara (ocaklara) dikilmektedir.

Dikim sırasında çukurun iki ucuna daha önce hazırlanan çeliklerden birer adet çelik, uç kısmı dışarıda kalacak şekilde çukur içine yatırılmakta ve çukurlar yarıya kadar toprakla doldurulmaktadır. Çukurlara dikimi yapılan bu çeliklerin uçları doldurulan toprak seviyesinin üzerinde 2 göz kalacak şekilde uçtan kesilmektedir. Dikimden itibaren 3 y1l boyunca her yıl 2 göz toprak dişında kalacak 


\section{Çizelge 1. Geleneksel bağcılıkta kullanılan terim ve kavramlar}

\begin{tabular}{|c|c|c|}
\hline Sira No & $\begin{array}{l}\text { Geleneksel } \\
\text { adlandırma }\end{array}$ & Güncel anlamı \\
\hline 1 & Ağırga & Bağlarda boşluk alanları doldurmak için fidan elde etme yöntemi. \\
\hline 2 & Bağlık & $\begin{array}{l}\text { Odunlara sarılan bir yaşlı dalları bağlamada kullanılan materyal (dut kabuğu lifi, geven } \\
\text { lifi, kumaş ip v.b) }\end{array}$ \\
\hline 3 & Baran & Bağlarda sıra arası boşluklar \\
\hline 4 & Ben & Meyvenin olgunlaşmadan önceki hali \\
\hline 5 & Ceyrik & Küçük salkım. \\
\hline 6 & Cingil & İki - üç taneli salkım \\
\hline 7 & Çengel & Budama yapılırken kuvvetli omcalarda 3-5 göz bırakılarak kesilen bir yaşlı dal \\
\hline 8 & Çor & Külleme hastalığg \\
\hline 9 & Çöçük & Salkım sap1 \\
\hline 10 & Çubuk & Bağlarda verim budamasında ürün almak için bırakılan bir yaşlı dallar \\
\hline 11 & Daldırma & Yaşlı bağlarda yeni fidan elde etmede kullanılan yöntem \\
\hline 12 & Derhe vurma & Yeni tesis edilmiş bağlarda gerçekleştirilen ilk budama işlemi \\
\hline 13 & Duvak & Üzüm tanesinin üzerindeki mumsu tabaka \\
\hline 14 & Eğrice & Fidan üretmek için kullanılan çelikler \\
\hline 15 & Garim & Eğimli arazilerde yağmur sularının toprağ \\
\hline 16 & Godafa & Üzüm sepeti \\
\hline 17 & Habbe & Üzüm tanesi \\
\hline 18 & Hit belleme & $\begin{array}{l}\text { Bağın kötü bellenmesi, yani toprağın belin ucuna gelen kısmını yarmadan toprağın } \\
\text { atılması }\end{array}$ \\
\hline 19 & Hon & Bağın bölümleri \\
\hline 20 & Karim & Fidan elde etmek üzere çeliklerin yatırıldığ 1 çukur \\
\hline 21 & Konguldak & Pazarlanamayacak düzeyde fazla kurumuş üzümler \\
\hline 22 & Koruk & Üzümün olgunlaşmadan önceki hali \\
\hline 23 & Kundak & Üzüm salkımı \\
\hline 24 & Kuyu & Bağ1 topraklamak için açılan toprak çukur \\
\hline 25 & Külleme & Toprağın bellenmeyen kısmının üzerine toprak sererek bellenmiş gibi göstermek \\
\hline 26 & Lik & Gevenden ip yapmak için geven sökmede kullanılan çatal sopa \\
\hline 27 & Ocak & Yeni bağ tesisinde fidan dikilecek çukur \\
\hline 28 & P1t & $\begin{array}{l}\text { Omcayı gençleştirmek için gövdenin dip kısmında bırakılan 2-3 göz üzerinden } \\
\text { kesilerek bırakılan dal }\end{array}$ \\
\hline 29 & Sarma & $\begin{array}{l}\text { Bağlarda budama sonrası bırakılan dalların üzümlerin yere değmemesi için sopaya } \\
\text { sarılması }\end{array}$ \\
\hline 30 & Sata & Omacanın gövdesi \\
\hline 31 & Sergen & Üzümün kurutmak için serildiği alan \\
\hline 32 & Serpene & Bir yaşlı dalların sarıldığ \\
\hline 33 & Teyek & Bağ \\
\hline 34 & Yavru & $\begin{array}{l}\text { Yaşlanmış ve yıpranmış asmalarda hasarlı bölümleri onarmak için bırakılan bir yaşlı } \\
\text { dallar }\end{array}$ \\
\hline 35 & Yenice & Yeni dikilmiş bağ \\
\hline 36 & Yetingeç & 2-3 yaşındaki omca \\
\hline 37 & Yük & $\begin{array}{l}\text { Yaş üzümlerin hayvanlarla taşınmasında kullanılan özel yapılmış sandıklardan iki adedi } \\
\text { bir yük olarak kabul edilir. Her sandık yaklaşık } 50 \mathrm{~kg} \text { yaş üzüm alır. }\end{array}$ \\
\hline
\end{tabular}


şekilde çukurun kalan boşluğu peyderpey doldurulmaktadır. Üçüncü yılın sonunda kök ve gövde gelişimini tamamlamış ve verime geçmiş omcalar elde edilmektedir.

\subsection{Geleneksel bağcılıkta kültürel uygulamalar}

Geleneksel bağlarda toprak işleme ilkbahar aylarında yılda bir defa bel ile yapılmaktadır. Belleme işlemine alt sıradan başlanmaktadır. Alt sırada araları belleyen işçi, üst sıranın altındaki omcaların kök boğazlarını da açarak gider. Üst sırada araları belleyen işçi de kök boğazlarını doldurarak gider. Belleme işlemi bitince, budamada bırakılan dallardan çıkanlar hariç, gövdeden ve kök boğazından çıkan sürgünler temizlenir. $\mathrm{Bu}$ işlem yılda üç defa tekrarlanmaktadır. Geleneksel bağlarda yaprak ve sülüklerin koparılması meyvelerin koruk döneminde yapılmaktadır. Asmalarda batı yönündeki yapraklar hariç salkıma gölge eden yapraklar ben düşme döneminden sonra koparılmaktadır. Koruk döneminden önceki dönemlerde salkımlara direk güneş 1şı̆̆ı geliyorsa bu kısımlar yaprak ya da otla gölgelendirilmektedir. Geleneksel bağcılık ilde sulama imkânının olmadığı alanlarda yapılmaktadır. Asmalar su ihtiyacını doğal yağışlarla karşılamaktadır. Geleneksel bağlarda gübreleme de yapılmamaktadır. Bağlarda verimi artırmak için parsellerin üst kısmında toprak kanallar açılarak (garim) burada yağmur sularının getirerek biriktirdiği yüzey toprağı omcaların dibine doldurulur. $\mathrm{Bu}$ uygulamaya ilde "bağ topraklama" adı verilmektedir.

\section{3. Geleneksel bağcılıkta budama}

Geleneksel bağlarda ilk y1l asmalar 3-4 göz bırakılarak tek dal üzerinden budanır ve herek (serpene) dikilerek bağlanır. $\mathrm{Bu}$ işlem omca gelişip toprak yüzeyinde gövde oluşana kadar 2-3 yıl tekrarlanır. Yerden 15-20 cm yüksekliğinde gövde oluşturulduktan sonra şekil budamalarına geçilir. Malatya ili geleneksel bağlarında; uzun serpene, kısa yatık serpene, kısa budama ve tek serpene olmak üzere dört farklı terbiye şeklinin oluşturulduğu görülmüştür.

\subsubsection{Uzun serpene terbiye şekli}

$\mathrm{Bu}$ terbiye şeklinde verim yaşına gelmiş omcaların kuvvet durumuna göre 1 veya 2 , bazen de 3 gövde (sata) oluşturulmaktadır. Oluşturulan gövdelerin üzerinde bulunan bir yaşlı dallardan kalın ve pişkin olan birinci, ikinci veya üçüncü dal bırakılıp, diğer dallar kesilmektedir. Ürün dalı olarak bırakılan dalın üzerinde bulunan sülükler ve gözlerden çıkmış olan sürgünler temizlenmektedir. Omcanın kök boğazı bel veya çapa ile açılarak yüzeye yakın kökler temizlenmekte ve açılan çukur tekrar doldurulmaktadır. Bırakılan dal, çeşitlere ve omcanın kuvvetine göre 5-12 göz bırakılarak son gözün 2-3 cm ilerisinden kesilmektedir. Baş serpene uç tarafa doğru yaklaşık 75 derece eğimle yere gömülmektedir. Dal, arazinin meyil durumuna göre serpenenin alt kısmına alınarak sarılmakta ve uca doğru uzatılmaktadır. Uç serpene arkaya doğru yaklaşık 75 derece eğimle yere saplanmakta ve serpene uçları bir birine yaslanmaktadır. Dalın ucu, uç serpeneye iple bağlanmaktadır (Şekil 1). 


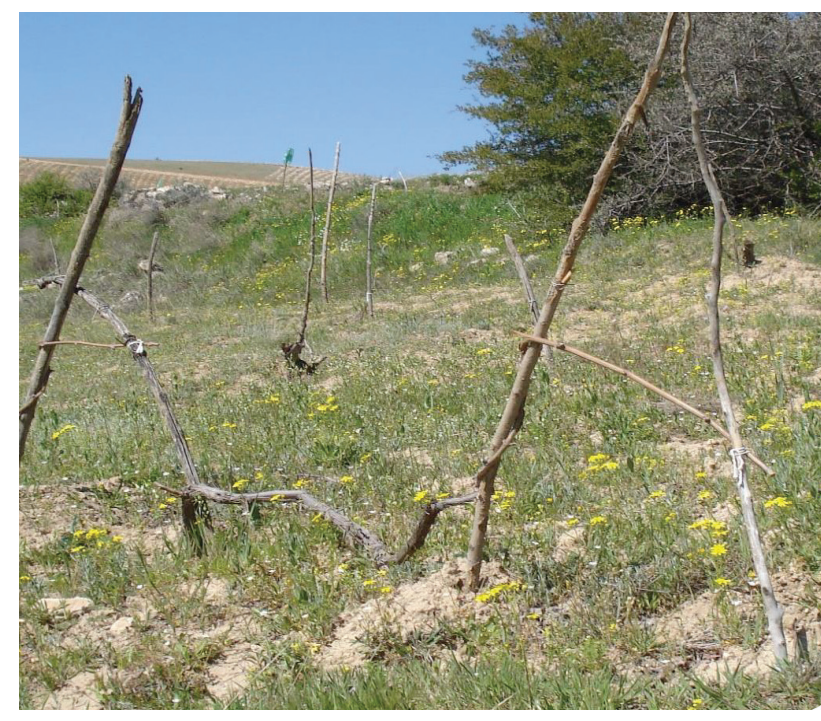

Şekil 1. Uzun serpene terbiye şekli

\subsubsection{Kısa yatık serpene terbiye şekli}

$\mathrm{Bu}$ terbiye şeklinde verim yaşına gelmiş omcaların kuvvet durumuna göre 1, 2, 3 veya 4 gövde (sata) oluşturulmaktadır. Oluşturulan bu gövdelerin üzerinde bulunan bir yaşlı dallardan kalın ve pişkin olan birinci, ikinci veya üçüncü dal bırakılarak diğer dallar kesilmektedir. Ürün dalı üzerinde bulunan sülükler ile bu dallar üzerinde bulunan gözlerden çıkan sürgünler temizlenir. Omcanın kök boğazı belle açılarak yüzeye yakın kökler temizlenir ve açılan çukur tekrar doldurulur. Baş serpene yaklaşı1k 75 derece eğimle çubuğun uç tarafına doğru 3. gözden hemen sonra yere gömülür. 3. göz ile 4. göz arasında dalda çıt sesi gelene kadar bükülür. İlk üç göz baş serpenenin gerisinde kalacak şekilde, serpenenin altından başlayarak dal serpeneye dolanır. İkinci olan uç serpene baş serpeneden 5-6 göz ileriye baş serpenenin eğimine paralel olarak yere gömülür. Dal yine üç serpeneye dolanarak yerden bir önceki bükülenin tersi istikamette çıt sesi gelene kadar bükülür. Bükme işlemi dalın sol elle sıkıca tutulup, sağ elle bükülmesiyle gerçekleştirilir. Dal bükülen yerden başlanarak uç serpeneye dolanır ve iki serpene arasında bulunan dala da dolanır ve baş serpeneye gelince kesilir. Gövde (sata) uzun ve yaşlı ise toprağa yakın yerde ve yukarı bakan dallardan bir tanesi 2 göz üzerinden kesilerek, gençleştirme budaması için bırakılır. İki serpene arasındaki gözlerden süren sürgünlerde salkım oluşurken, ezilen kısımların dışında kalan gözlerden süren sürgünlerde ise genellikle salkım oluşmaz (Şekil 2).

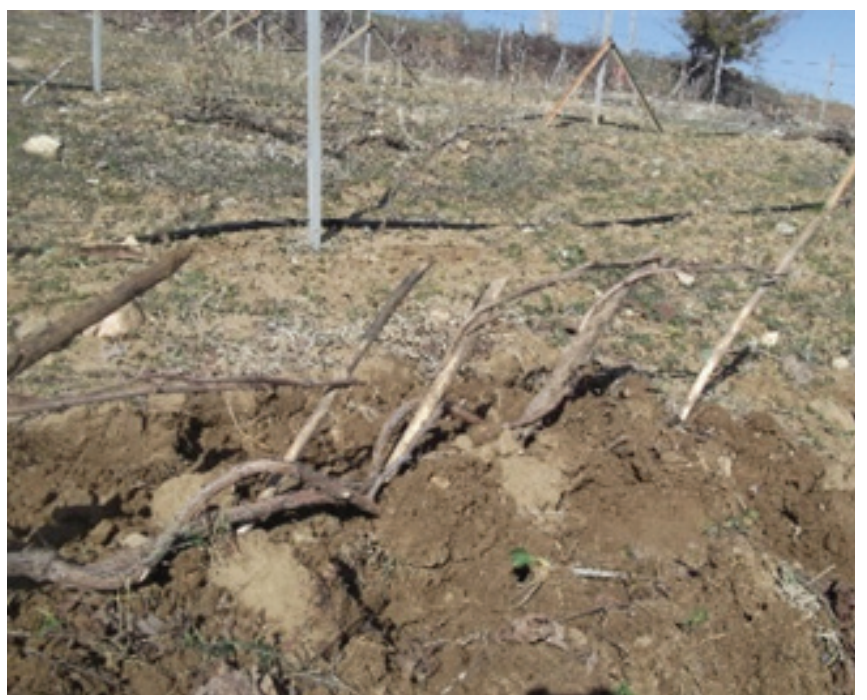

Şekil 2. Kısa yatık serpene terbiye şekli

\subsubsection{Kısa budama terbiye şekli}

$\mathrm{Bu}$ terbiye şeklinde verim yaşına gelmiş omcalarda öbek halinde $2,3,4,5$ veya 6 k1sa gövde (sata) oluşturulmaktadır. $\mathrm{Bu}$ gövdeler toprak altından çıkan dip sürgün üzerinde 
gelişen dallardan oluşturulur. Gövdede bulunan kalın ve pişkin dallar 2, 3 veya 4 göz üzerinden kesilir. Her gövdede (sata) bu şekilde 1, 2 veya 3 dal bırakılır. Gövdeler uzayınca dipten kesilir ve dip sürgününden çıkan sürgünlerden tekrar gövde oluşturulur (Şekil 3).

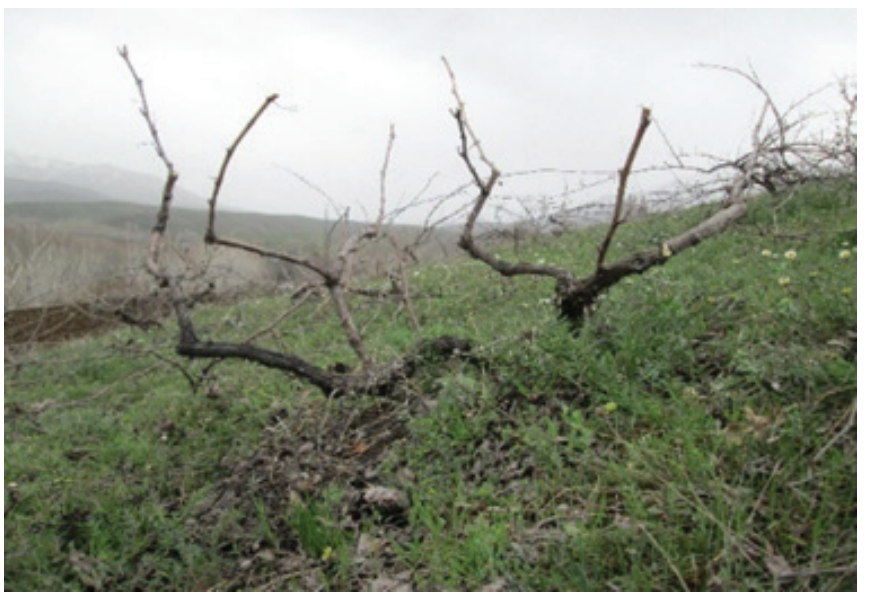

Şekil 3. Kısa budama terbiye şekli

\subsubsection{Tek serpene terbiye şekli}

$\mathrm{Bu}$ terbiye şeklinde diğer budama yöntemlerinden farklı olarak hendekler yaklaşık $1.5 \mathrm{~m}$ derinliğinde açılmaktadır. Hazırlanan dipçikli çeliklerin dipçik kısmı 10-15 gün suda bekletilir. Suda bekletilmiş çelikler sonbaharda $2 \mathrm{~m}$ aralıklarla çukurlara dikilir ve yaklaşık 1 m toprakla doldurulur. Dalların tepesi 5-6 göz toprak üstünde kalacak şekilde kesilir. Bağ her yıl bellendikçe hendek doldurulur. Dallar her yı1 1-2 göz üzerinden budanır. Gövdenin 50-60 cm uzunluğunda ve dik oluşması için sopaya (serpene) bağlanır. Bu şekilde 3-4 yılın sonunda omcalarda gövde oluşturulmaktadır. Tek serpene terbiye sisteminde oluşturulan gövde üzerindeki dallardan 2. veya 3. dal birakılarak diğerleri kesilir. Bırakılan dal 3. göz ile 4. göz arasındaki kısımdan sağa sola bükülerek kopmayacak şekilde kırılır. Serpene gövdeye yaklaşık 75 derece eğimle toprağa gömülür. Üçüncü göz serpenenin dişında kalacak şekilde dal serpeneye dolanır. Dalın ucu toprağa yaklaşık $20 \mathrm{~cm}$ kala, gözün 2-4 cm ilerisinden kesilir. Bir sonraki yıl serpenenin dışında kalan gözlerden çıkan sürgünlerden kaliteli ise 3 . sürgün, değilse 2. sürgün dal olarak bırakılır. Yaşlanmış ve fazla uzamış omcalarda gövdenin dik olarak büyütülen bölümün bittiği kısımlara yakın yerlerden çıkan sürgünlerden biri bırakılır. Bir sonraki budamada bu sürgün 2-3 göz bırakılarak gövde kesilerek gençleştirilir ve gövde kısaltılmış olur (Şekil 4).

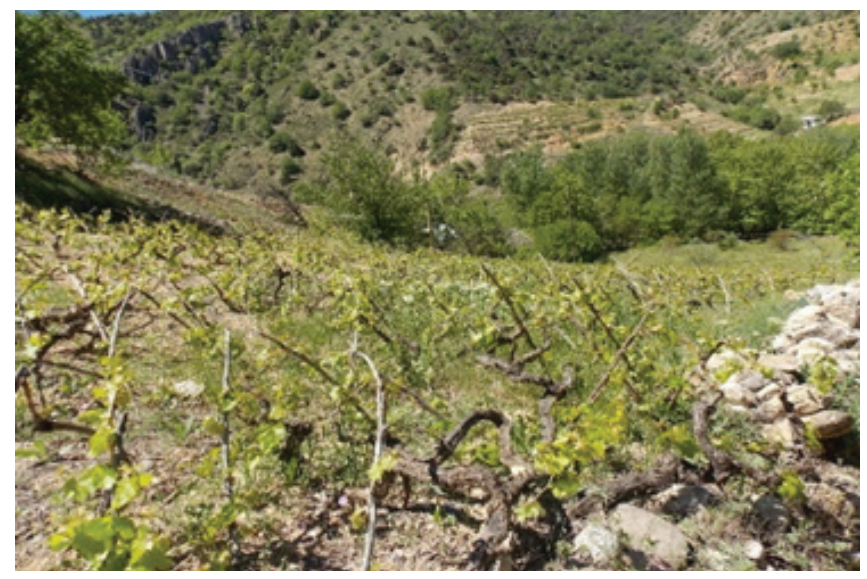

Şekil 4. Tek serpene terbiye şekli

\subsection{Hasat ve Bağ bozumu}

İlde üzümler, çeşitlerin olgunlaşma dönemleri dikkate alınarak sofralık, şıralık ve kurutmalık olmak üzere tüketim ve pazarlama amacına göre farklı şekillerde hasat edilmektedir. Hasattan sonra hemen pazara sunulacak sofralıklar 
çeşitler, salkım sapından tutularak ve tanelere el değdirmeden salkım sapından kesilir. Daha sonra salkım üzerindeki bozuk ve çürümüş taneler makasla kesilerek ayıklanır. Şıralık çeşitlerin hasadında hasat zamanı biraz geciktirilmektedir. İyice olgunlaşan salkımlar salkım sapından kesilerek sand1k ve sepetlere (godafalara) doldurulup işlenecek alana taşınır. Kurutmalık çeşitlerin hasadında ise yine salkımlar saplarından makasla kesilir. Kesim esnasında üzüm tanelerine el değmemeye özen gösterilir. Büyük salkımlar, kurutmanın daha kısa sürede ve diğer salkımlarla aynı zamanda kuruması için küçük parçalara ayrılır. Hasat edilen üzümler sepetlere doldurularak kurutma alanına taşınır. Sonbaharda hasat işlemi tamamlanan bağlarda bağ bozumu yapılmaktadır. Bağ bozumunda ilk olarak dalların bağlı olduğu ön serpendeki ip kesilerek serpeneler topraktan çıkarılır. Omca toprak üstüne yatırılır, serpeneler omacanın üzerine bırakılır. $\mathrm{Bu}$ yöntemle omcanın kışın kar altında kalması sağlanarak, soğuktan zarar görmesi engellenir.

\subsection{Zirai mücadele}

Geleneksel bağcılıkta çiftçiler bağ hastalık ve zararlılarından bağ uyuzu ve külleme (çor) ile mücadele etmektedirler. Bağ uyuzu ile mücadelede toz kükürt kullanılmaktadırlar. Külleme (çor) ile mücadelede ilk olarak bağda üzümlerin koruk olduğu dönemde omcanın etrafı çapalanır ve yaprak alımı yapılır. Ayrıca toprak yollarda yürüme sonucu oluşan tozlaşmış toprak ince gözenekli bezlerle salkımlara toz halinde serpilir. Daha sonraki yıllarda toz kükürt ile odun külü karıştırılarak yine bezlere konularak toz halinde salkımların üzerine serpilir. Bu işlem sabah güneş doğmadan önce serin havalarda belli dönemlerde (sürgünler yaklaşık bir karış olduğunda, salkımdaki taneler mercimek büyüklügüüne geldiğinde ve tanelerin koruk döneminde) üç defa tekrarlanmaktadır. Geleneksel bağcılıkta yabancı ot mücadelesinde ilkbahar yağmurları sonrasında haziran ay1 başlarında toprak bellenir. Koruk döneminde ise genç ve yaşlı bağlarda omçaların dibi çapalanır.

\subsection{Kurutma}

Malatya ilinde geleneksel bağlarda kurutmalık amaçla yetiştirilen en yaygın çeşit yöresel "Banazı Karası" çeşididir. Hasat döneminde olgunlaşan salkımlar kesilerek sergenlerde kurutmaya alınır (Şekil 5). Kesime başlamadan öce sergen alanı ot, taş gibi maddelerden temizlenir, toprak çiğnenerek sıkıştırılır. Salkımlar kesilirken salkım sapından (çöçük) tutulur, tanelere el değmemesine dikkat edilir. Mumsu (duvak) tabakanın silinmemesi istenir. Sergen yerlerine sepetlerle (godafa) taşınır. Salkımlar yere dizilirken çok büyük salkımlar makasla kesilerek küçültülür. Salkım sapları yukarı gelecek şekilde yere bırakılır. 5-6 gün sonra salkımlar ters çevrilir, alt kısmı da kuruyan küçük salkımlar toplanır. 4-5 gün sonra kuruyan salkımlar toplanır, büyük salkımlar kuruyana kadar beklenir. Banazı karası, soğuk depolarda muhafaza edilmez. Soğuk yerde muhafaza edilirse şekerlenir.

İlde sofralık olarak yetiştirilen ancak pazarda 
sofralık satım kalitesinin yakalanmadığ 1 durumlarda Mikeri, Peygamber Üzümü, Hatun Parmağ1 ve Beyaz Boğazkere çeşitlerine ait üzümlerin de kurtulması sınırlı düzeyde yapılmaktadır. $\mathrm{Bu}$ çeşitlere ait üzümler ilde yağlanarak kurutulmaktadır. Tanelenen üzümlerin yağlanması için iki farklı yöntemin gerçekleştirildiği görülmüştür. Bunlardan ilki; eritilen tuzsuz tereyağına bir miktar odun külü karıştırılmakta ve tanelenen üzümler bu yağa bulanarak beze serilmektedir. Diğer yöntemde ise yağlamada hafif 1 sıtılmış yemeklik ayçiçek yağı kullanılmaktadır. Bu yöntemde de yağlanan taneler bezlere serilerek kurtulmaktadır.

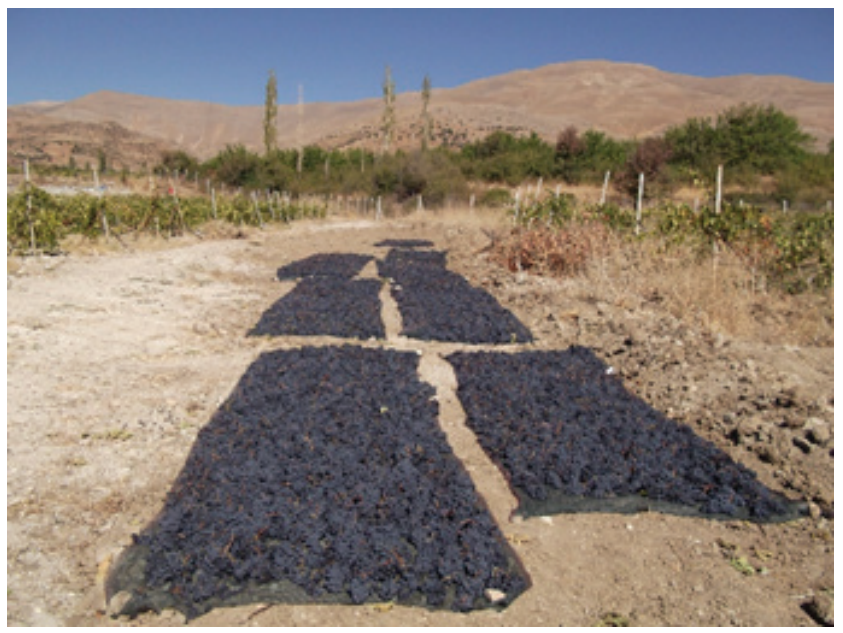

Şekil 5. Geleneksel bağcılıkta üzümlerin kurutulması

\subsection{Yaş depolama}

İlde sofralık olarak üretilen Mazırım, Köhnü ve Aşık Beyazı çeşitleri taze olarak pazarlarda satılmaktadır. Taze satımın yanı sira bu çeşitler depolanarak ileride yaş üzüm olarak da satılmaktadır (Şekil 6). Depolanan bu çeşitler geç olgunlaşmakta ve depoya dayanıklı çeşitlerdir. $\mathrm{Bu}$ çeşitlerin depolanmasında iki farklı yöntem kullanılmaktadır. Birinci yöntemde üzümler salkım sapından tutularak kesilir. Meyvenin üzerindeki mumsu tabakanın kalması istenir. Evlerin don olmayan serin odalarının tavanındaki direklere çiviler çakılır ve salkımlar bu çivilere asılır. Çivilere asılan salkımların sapındaki kesim yapılan uç kısmına, su kaybı olmaması için bir adet üzüm tanesi geçirilir. Yaş depolamada ikinci yöntemde ise; omacanın dibine 50-60 $\mathrm{cm}$ derinliğinde çukur açılır. Sopa üzerine üzüm salkımları boşlukta sallanacak şekilde omcayla birlikte uzatılır. Üzerine naylon bez veya yapraklı meşe dalları konur ve daha sonra üzeri toprakla kapatılır.

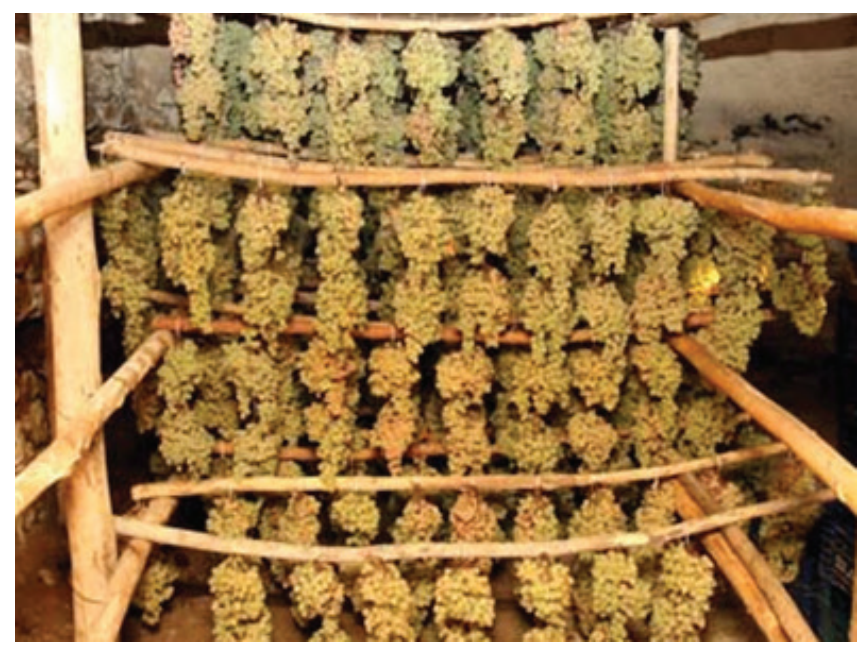

Şekil 6. Geleneksel bağcılıkta yaş üzümlerin depolanması (Anonim, 2017) 


\section{KAYNAKLAR}

\section{SONUÇ}

Geleneksel uygulamalar ülkeler için tarihi miras niteliğindedir. Ülkemizde geleneksel giyim kuşam, geleneksel gidaların üretimi ve geleneksel mimari uygulamalarının derlenmesi ve muhafazasına yönelik pek çok çalışma yapılmaktadır. Ancak eski çağlardan beri önemli bir tarımsal kültür birikimi olan ülkemizde geleneksel tarım tekniklerinin derlenmesine yönelik çalışmalar sınırlı düzeydedir.

Tarım ve Orman Bakanlığı'nca desteklenen ve 2014-2016 yıllarında yürütülen bu çalışmada, ülkemizin önemli bağcılık merkezlerinden olan Malatya ilinde geleneksel bağcılıkta kullanılan terim ve kavramlar ile bağ tesisi ve kültürel uygulamalara ait bilgiler derlenmiştir. Çalışma sonunda geleneksel bağcılıkta 37 farklı terim ve kavramın kullanıldığı belirlenerek bunlar güncel anlamlarıyla birlikte kayıt altına alınmıştır. Ayrıca geleneksel bağcılıkta uygulanan bağ tesisi, geleneksel bağlarda kültürel uygulamalar, zirai mücadele ile ürünlerin kurutma ve depolamasında kullanılan geleneksel yöntemler derlenerek muhafaza altına alınmıştır.
Altun, İ., 2015. Kahramanmaraş-Elbistan'da geleneksel olarak yapılan tarhana ve tarhana çorbası. Iğdır Üniversitesi Fen Bilimleri Enstitüsü Dergisi, 5 (1) : 45-49.

Anonim, 2017. http://malatyahaber.com/haber/ kis-ortasinda-salkim-salkim-taze-uzum/ (Erişim tarihi: 27.03.2019)

Anonim, 2018. http://www.kulturvarliklari.gov. tr/TR,43880/malatya-muzesi-mudurlugu. html (Erişim Tarihi: 25.12.2018).

Anonim, 2019. Malatya İl Tarım ve Orman Müdürlüğü İstatistikleri.

Arıŏlu, İ. E., Aydoğdu Atasoy, Ö., 2015. Somut olmayan kültürel miras kapsamında geleneksel el sanatları, Kültür ve Turizm Bakanlığ1, Electronic Turkish Studies, 10 (16):109-126.

Bayındır, Y., Çöçen, E., Macit, T., Gültekin, N., Toprak Özcan, E., Aslan, A., Aslantaş, R., 2018. Malatya yöresi mahalli güzlük armut genotiplerinin seleksiyonu. Akademik Ziraat Dergisi, 7 (1): 9-16.

Bülbül, P., 2017. Eski Anadolu'da tarım faaliyetleri, Uluslararası Tarih ve Sosyal Araştırmalar Dergisi 9 (17) : 269 - 282.

Çelik, H., Ağaoğlu, S., Fidan, Y., Marasalı, B., Sölemezoğlu, G., 1998. Genel Bağcılık. Sunfidan A.Ş. Mesleki Kitaplar Serisi 
1, Fersa Matbaacılık San. Tic. Ltd. Şti., Kizılay, Ankara, 253 s.

Çöçen, E., Macit T., Ernim C., Kokargül R., Uğur Y., Kan T., Pırlak L., 2018. Malatya Yöresinde Yetiştirilen "Arapkızı" Elma Çeşidinde Klon Seleksiyonu, Meyve Bilimi; 5(2):43-48.

Ergenoğlu, F., Tangolar, S., 2000. Bağcılık İçin Pratik Bilgiler. TÜBİTAK, Türkiye Bilimsel ve Teknik Araştırmalar Kurumu, TARP, Türkiye Tarımsal Araştırma Projesi Yayınları, Adana.

Karakaya, M., Tiske, S.S., 2009. Et tarhanas1. Geleneksel gidalar sempozyumu, 27-29 May1s 2009, Van, 108-110.

Keskin, N. 2011. Van'da Geçmişten Günümüze Bağcılık. Bağbahçe Çevre Bahçe Çiçek Dergisi, 35: 26-27.

Keskin N., 2017. Elazı̆ ilinde yetiştirilen bazı yerli üzüm çeşitlerinde verim ve kalite özellikleri arasındaki ilişkilerin belirlenmesi. Türkiye Teknoloji ve Uygulamalı Bilimler Dergisi, 1:25-30.

Keskin, N., Kunter, B., Alaeddinoğlu, F. 2018. Van ve yöresinin atasal çeşidi erciş üzümünün agroturizm değeri. Uluslararası Batı Asya turizm araştırmaları kongresi, 26-29 Eylül 2018, Van, 705-710.
Türkiye'de bağcılık turizmi. Uluslararası Kırsal Turizm ve Kalkınma Dergisi, 1 (2) : $29-34$.

TUİK, 2019. Türkiye İstatistik Kurumu https:// biruni.tuik.gov.tr/bitkiselapp/bitkisel.zul (Erişim Tarihi: 07.01.2019).

Türkben, C., Gül, F., Uzar, Y., 2012. Türkiye’de bağcılığın tarım turizmi (Agro-Turizm) içinde yeri ve önemi. KMÜ Sosyal ve Ekonomik Araştırmalar Dergisi, 14 (23) : $47-50$.

Ülkümen, L., 1938. Malatya'nın Mühim Meyve Çeşitleri Üzerinde Morfolojik, Fizyolojik ve Biyolojik Araştırmalar. Yüksek Ziraat Enstitüsü Rektörlüğü, Ankara, say1 65. 